Contemporary Research in Education and English Language Teaching

ISSN: 2641-0230

Vol. 1, No.4, pp. 57-62

2019

Publisher: Learning Gate

DOI: $10.33094 / 26410230.2019 .14 .57 .62$

(C) 2019 by the authors; licensee Learning Gate

\title{
The Effect of Storytelling on Longer Vocabulary Retention
}

\author{
Veronika Bežilová \\ PhD. Student, Institute of British and American Studies, Faculty of Arts, University, Slovakia
}

Received: 17 October 2019; Revised: 14 November 2019; Accepted: 4 December 2019; Published: 23 December 2019

Abstract: Storytelling is one of the oldest forms of sharing important events in human's lives. It has been claimed that stories are one of the most powerful tools for language learning. Children enjoy listening to same stories again and again; therefore, they can acquire a lot of vocabulary and sentence structures. Present study examines the effect of storytelling on longer vocabulary retention. Data were collected over five weeks and the case study focuses on children's vocabulary retention over a period of time. The study also focuses on the importance of supplementary materials and activities that should be connected to the storytelling. The paper points out the importance of the storyteller's preparation.

Keywords: Storytelling, Stories, Vocabulary, Retention

\section{Introduction}

Stories are one of the oldest forms of human communication. Stories have been used for different purposes as education or entertainment. Furthermore, stories have been used as an effective and powerful tool in EFL. Stories are used to develop language skills, regardless the learner's age. Additionally, they also represent an experience, which is important tool for teaching young learners. Stories offer children the ability to know what to expect from the stories. Repetition, which is present in the stories, enables children to learn new phrases, vocabulary; moreover, they can predict what will happen.

Children are keen to listen to the stories not only in their mother tongue, but also in the foreign language. They can predict what will happen after the well-known phrase "Once upon a time"; moreover, this phrase also activates children's imagination, fantasy and curiosity which are important for learning in general. The curiosity causes that children are internally motivated; therefore, there is also higher possibility that they will remember words, or phrases. S. Mat'ková (2010) claims that fantasy is very important, and without it there will be stagnation in other areas of cognition; therefore, it is important for teachers to develop and support children's fantasy and imagination. For children, it is natural to listen to stories, to understand the world through rules that appear in stories (to distinguish between good and bad, what does it mean to be poor or rich, how to treat older people, ...).

S. Mat'ková (2010) states that children's perceptiveness is spontaneous. Perceptiveness should be cultivated and supported by the education. Children have short attention span; therefore, it might be hard for them to concentrate on listening. Storyteller should choose short texts as rhymes, or short stories. To make the comprehension as easy as possible, the storyteller should use simple concepts, pictures, body language, voice modification. This research aims to investigate the effect of storytelling on vocabulary retention.

\subsection{Reasons for Using Stories}

Children enjoy listening and reading stories. Stories represents an ideal introduction to foreign language, as their context is often familiar to children. There are many reasons why stories should be 
used in language lessons. In general, literature allows children not only to understand but also to appreciate cultures different from their own.

Ellis and Brewster (2002); Mat'ková (2010); Gómez (2010) state several reasons for using stories in the classrooms:

- Stories are motivating and challenging; moreover, they are also fun and might help children to develop positive attitude towards the foreign language and its culture.

- Stories exercise imagination and fantasy. Children can be personally involved in the storytelling (when they identify with some of the characters). This personal experience helps them to develop their own creative skills.

- Stories are also understood as a valuable tool for linking the imagination and fantasy and child's real world. Stories also help children to understand their everyday life.

- Listening to stories is a shared social experience and children can share their reactions as excitement, laughter, sadness, or fear. This experience has social and emotional value, which plays a vital role not only in child's emotional skills, but also social.

- Children enjoy listening to stories they've already heard. This repetition allows certain language items to be acquired, others to be reinforced. Repetition also allows children to participate in the storytelling; moreover, it also strengthen the retention of vocabulary. It is also assumed that listening to stories supports internal motivation, which causes that the retention is longer.

- Through the listening, new vocabulary can be introduced, or revised. Stories also develop different types of intelligences that contribute to language learning

- Through the stories, child can learn strategies as listening for specific information, guessing the meaning, predicting.

- Storytelling can be accompanied by different materials as puppets, pictures, or different activities in which children can experience the language (instead of explaining what it means to close the door it can be shown, consequently the child is asked to close the door - child experiences what it means to close the door)

\subsection{Using Stories for Longer Vocabulary Retention}

There is number of studies which investigate the effect of storytelling on longer vocabulary retention. Kirsch (2012) focuses on using storytelling in language lessons. Her study investigates the teaching strategies as well as children's language use. The research was administered with two storytelling events. Kirsch also examines the sentences, which were recalled firstly at the end of the storytelling lesson, and secondly after several weeks. The results of the research show that children were able to recall and retain a significant number of sentences and words. The results show that all research participants retained almost all of target vocabulary.

Zi-Gang Ge (2015) investigates whether the retention of target words can be enhanced by the usage of Storytelling. The results show that storytelling approach have more facilitating effect on the longterm vocabulary retention. The questionnaire survey also shows that storytelling method is appreciated by the majority of experimental group. The important Zi-Gang Ge's finding is that storytelling approach increases not only short-term vocabulary, but also long-term retention. Lorenzo (2012) focuses on the effect of play and storytelling on vocabulary retention and acquisition. Lorenzo claims that teaching through storytelling approach allows children to enhance their vocabulary in a different mode which can be achieved through retelling the same story, dramatizing the story through the game or play. The research offers interesting results. The post-test showed that the control group retained eight of the target vocabulary, while the experimental group retained only five. Lorenzo says that the problem might be the text presentation. The experimental group was usually read the story as first, which also means that the experimental group represented a practice in storytelling for the teacher. 
Ansarin and Khojasteh (2013) focus on the vocabulary retention. Their study talks about effectiveness of intentional and explicit methods vocabulary teaching which is compared to incidental methods. The results show that the reason for the lowest score in post-test was the length of the dictionary definitions which was presented to the learners. The group with the middle score achieved relatively higher results due to fact that provided meanings were the shortest among the three groups. The third group which was using context method proved to be most successful in the vocabulary retention. The authors claim that conveying meaning through the context is more effective way than using dictionary definitions or synonyms. The authors also suggest using revision and recycling activities in vocabulary acquisition.

Nation (2007) speaks about "four strands of vocabulary learning" that "need to be present in roughly equal proportions in a well-balanced language course" (Nation, Meara, 2010, p.38), namely:

- Learning Vocabulary from Meaning-focused Input (Listening and Reading)

- $\quad$ Learning Vocabulary from Meaning-focused Output (Speaking and Writing)

- Deliberate Vocabulary Learning

- Developing Fluency with Vocabulary across the Four Skills

Storytelling enables combinations of exposure as well as both, incidental and deliberate vocabulary learning. What more, it not only brings the word in the context but also enables to develop automaticity by active, meaningful rather than rote learning.

The vast majority of studies focus on the role of storytelling on vocabulary retention or on the development language skills. Studies also seem to support the idea that storytelling is effective motivating tool in EFL; moreover, it also enhances children's productive and receptive skills. All above mentioned studies indicate that storytelling is very useful teaching tool. Subsequently, they show that storytelling helps young learners to improve language skills.

\section{Methodology}

Before the selection of the case group, the study investigates the usage of narrative technique storytelling in foreign language teaching. Both groups experience storytelling technique, as the presentation of new vocabulary, sentence structures and phrases. For this research was chosen only one of the groups as a case study. The research is based on an ethnographic approach as the researcher was not only observing, but also interacting with the study's participants. Children's reaction to the story and their ability to recall the target vocabulary and parts of the language was observed. Post-tests are in the form of children's ability to retell the story, to name the pictures, to use the phrases from the story.

\subsection{Participants}

Two EFL groups $(\mathrm{n}=12 ; 4 \mathrm{~F}, 8 \mathrm{M}$; age 8 -9) taught by the same teacher in a private language school were the subject of the present study. Children attend different primary schools, none of them are classmates. The convenience sampling was applied (two groups taught by the researcher). The selected participants have been studying English for two years.

\subsection{Procedure and Instruments}

The material was selected considering age of learners, attention span, their interests and language proficiency. The story Dark, dark wood was used. The story was not long, it took no more than threefour minutes.

The narrator used the non-verbal communication, supported by pictures, as well as intensively worked with her voice. The listening was followed by the activities, mainly games, aimed at learning target vocabulary and sentence structures. Subsequently, the story was narrated again, but this time the storyteller paused in some parts and children were supposed to continue in telling the story. At the end of the session children were given pictures with the target vocabulary and their task was to tell the story on their own. 
Two post-tests were administered. The first post-test consisted of picture and vocabulary recognition. The first post-test was administered two weeks after the teaching session flashcards were used to test vocabulary and phrases from the story.

The second post-test was administered 5 weeks from the first session. The video story was used to support learners to retell the story. To remind the content of the story and to check whether children remember the plot, they were asked to put the pictures for the story into the correct order. In the next stage the video story was used with the sound switched off. Children were said that TV was broken, and they had to dub the video. Only child 1 was able to retell the story, however the rest of the group did not remember the phrases. They (child 2, 3 and 4), however, were able to join child 1 in dubbing when they heard the beginning of the story. The video was dubbed more than once so that the child 5 would be able to product language on his own so he would feel involved and satisfied, the main reason for this was to strengthen positive relationship with the foreign language.

All lessons that were focused on the story Dark, dark wood showed children's enthusiasm and their ability to acquire vocabulary. Storytelling was supported by the flashcards, different activities and games that took place after the listening to the story. During the preparation, one of the most important things was working with the storyteller's voice (since the stories are natural to children and they also make them curious) so the story would be more dramatic and scary. Important were also non-verbal clues, as eye contact, gestures, facial expression.

\section{Results}

At the end of the first session, three out of five children were able to retell the story themselves (with the usage of the pictures); one of them was able to retell the story with the help of the rest of group and the last child was able to name the objects in the pictures, but was not able to used phrases (in the ... there was ...).

The first post-test shows that all of children remembered the vocabulary, but only four of them were able to use the words in speaking. One of the boys understood the vocabulary, he was able to point at the correct picture, but he was not able to name the pictures; moreover, he also did not remember the phrases. Considering the target phrases, the results were the same as during the first session. Only two children were able to retell the story by themselves. Child 3 and child 4 were able to label the pictures and put them in the correct order, but they were confused with the usage of the phrases connected to the story. However, after he listened to story at the end of the second lesson he was also able to retell the story.

Table 1.

Retention of vocabulary and phrases

\begin{tabular}{|c|c|c|c|c|c|c|}
\hline & $\begin{array}{l}\text { Teaching } \\
\text { lesson }\end{array}$ & Teaching lesson & $\begin{array}{l}1^{\text {st }} \text { post-test (in } \\
\text { two weeks) }\end{array}$ & $\begin{array}{l}1^{\text {st }} \text { post- } \\
\text { test }\end{array}$ & $\begin{array}{l}2^{\text {nd }} \text { post- } \\
\text { test (in } \\
\text { five } \\
\end{array}$ & $2^{\text {nd }}$ post-test \\
\hline Child & Vocabulary & Phrases & Vocabulary & Phrases & Vocabulary & Phrases \\
\hline $\begin{array}{l}\text { Child } \\
1\end{array}$ & $\checkmark$ & $\checkmark$ & $\checkmark$ & $\checkmark$ & $\checkmark$ & $\checkmark$ \\
\hline $\begin{array}{l}\text { Child } \\
2\end{array}$ & $\checkmark$ & $\checkmark$ & $\checkmark$ & $\checkmark$ & $\checkmark$ & $\checkmark$ \\
\hline $\begin{array}{l}\text { Child } \\
3\end{array}$ & $\checkmark$ & $\checkmark$ & $\checkmark$ & $\checkmark$ & $\checkmark$ & $\begin{array}{l}\text { He was able to recall } \\
\text { the phrases only } \\
\text { after he listened to } \\
\text { the beginning of the } \\
\text { story }\end{array}$ \\
\hline
\end{tabular}




\begin{tabular}{|l|l|l|l|l|l|l|}
\hline $\begin{array}{l}\text { Child } \\
4\end{array}$ & $\checkmark$ & $\begin{array}{l}\text { With the help the } \\
\text { classmates }\end{array}$ & $\checkmark$ & $\checkmark$ & $\begin{array}{l}\text { He was able to recall } \\
\text { the phrases only } \\
\text { phter he listened to } \\
\text { aftering of the } \\
\text { the beginning } \\
\text { story }\end{array}$ \\
\hline $\begin{array}{l}\text { Child } \\
5\end{array}$ & $\checkmark$ & - & $\begin{array}{l}\text { He understood } \\
\text { but was not able } \\
\text { to use it. }\end{array}$ & - & - \\
\hline
\end{tabular}

\section{Discussion of Findings}

Previous studies evaluating storytelling and vocabulary retention observed consistent results on whether the storytelling influences the length of retention. The pedagogical studies on the use of stories in EFL share unifying results. The results show that stories support long-term memory retention. According to Kirsch (2012) stories play an important role also in the student's motivation and positive attitude towards the target language. The finding is also supported by Zi-Gang Ge (2015) who claims that majority of the participants appreciated the storytelling technique.

The current study finds that there is a connection between storytelling and longer vocabulary retention and therefore it can support claims of above mentioned studies. Present study also shows the importance of accompanying activities, which helped children to use the target vocabulary and phrases. This finding can be supported by Gómez (2010, p. 49) who claims: "Children want to invent and rete things in order to play and have fun and, finally, they are also curious, so they want to experiment. These activities take advantage of these features and help involve him/her in the story and to create positive attitude towards English learning." These outcomes are contrary to Lorenzo (2012), whose findings show that play and game do not support vocabulary retention. Lorenzo's findings show that experimental group retain less target words than control group.

In accordance with the present results, previous studies have demonstrated that storytelling supports motivation, children's fantasy and imagination, strengthens positive attitude towards the target language. Furthermore, it is also claimed that storytelling helps the long-term vocabulary retention; therefore, it should be used during on EFL classes. An overall comparison of the means showed that storytelling influenced longer vocabulary retention.

\section{Conclusion}

The present study focuses on the narrative technique storytelling and its ability to present not only new vocabulary, but also sentence and grammatical structures to young learners and its effect on vocabulary retention. The findings show that stories support children's motivation to stay focused; moreover, it also represents a source of curiosity for them. The fact that they enjoyed their own storytelling shows that they were engaged throughout the storytelling lessons. Children were also able to recall the target vocabulary and phrases over a period of time which shows that storytelling influenced the retention of vocabulary. Several explanations may be given: the target phrases tented to reappear throughout the story; the target language was used in different types of activities after the storytelling itself; the story awoke children's curiosity and therefore they stayed focused. Even though the stories are great motivating factor for children, teachers' preparation is the key to children's ability to remember target parts of the language. Language should be accessible to children; the teacher should use a lot of scaffolding and work with his/her voice, so the storyteller catches children's attention.

There are some limitations to this study. Some of the children are not used to speak in English, they still need a lot of exposure to the target language before they start speaking. Thus, for future storytelling, more time should be spent on providing support for the children, so they would be confident enough to speak and take part in the activities.

The present study also shows that using storytelling technique brings curiosity, internal motivation to the class. When the children are internally motivated, they are also focus on what is going on in the 
class. Many children can relate themselves to the main characters of the stories; they can learn to distinguish between good and bad. Stories illustrate, enlighten, inspire, and educate; therefore, they make the learning process more effective.

\section{References}

Ansarin, A., \& Khojasteh, R. (2013). Retention in Meaning-Based Vocabulary Instruction. SKY Journal of Linguistics, 26, 7-19. Retrieved from https://pdfs.semanticscholar.org/3c87/889d561775aob2cd111f818568121e060397.pdf

Brewster, J., Ellis, G., Girard, D. (1992). The primary English teacher's guide. London: Penguin Group.

Brown, J. D. (1991). Understanding Research in Second Language Learning ( $3^{\text {rd }}$ ed). Cambridge: Cambridge University Press.

Dujmović, M. (2006). Storytelling as a method of EFL teaching. Metodički obzori. pp. $75-87$. Retrieved from https://hrcak.srce.hr/index.php?show=clanak\&id_clanak_jezik=17682

Ellis, G., Brewster, J. (2002). Tell it Again. Edinburgh Gate: Pearson Education Limited.

Ge, Z-G. (2015). Enhancing Vocabulary Retention by Embedding L2 Target Words in L1 Stories: An Experiment with Chinese Adult e-Learners. In Educational Technology \& Society. pp. 254- 265. Retrieved from https://www.j-ets.net/ETS/journals/18_3/20.pdf

Gobo, G. (2001). Ethnographic methods. Retrieved from https://www.researchgate.net/publication/279406124_Ethnographic_methods

Gómez, A. B. (2010). How to use tales for the teaching of vocabulary and grammar in a primary education English Class. RESLA, 23, pp. 31 - 52. Retrieved from https://www.researchgate.net/publication/269109139_How_to_use_tales_for_the_teaching_of _vocabulary_and_grammar_in_a_primary_education_English_class

Hitková, P. (2017). Zlepšovanie postoja žiakov k angličtine ako vyučovaciemu predmetu pomocou naratívnych techník a autentických kníh. In Scientia et Eruditio. pp. 67 -84. Trnavská univerzita v Trnave.

Kirsch, C. (2012). Using storytelling to teach vocabulary in language lessons: does it work? The Language Learning Journal. Retrieved from https://www.tandfonline.com/doi/full/10.1080/09571736.2012.733404

Lorenzo, J. (2012). The effects of storytelling and play on vocabulary acquisition and retention in young children.

Retrieved from https://www.pulib.sk:2333/docview/1016169882/AE57167432FC4B8APQ/1?accountid=1471 6

Lucarevschi, C. R. (2016). The role of storytelling in language learning: A literature review. In Working Papers of the Linguistics Circle of the University of Victoria. pp. 24 - 44. Retrieved from https://journals.uvic.ca/index.php/WPLC/article/view/15309

Mat'ková, S. (2010). Rozprávanie príbehu ako dobrý úvod do vyučovania anglického jazyka. In Z. Straková \& I. Cimermanová (Eds.) Učitel’ cudzieho jazyka v kontexte primárneho vzdelávania. (pp. 122 - 143). Prešov: Prešovská univerzita v Prešove.

Mellon, N. (2000). Storytelling with Children. Gloucestershire: Hawthorn Press.

Morgan, J., Rinvolucri, J. (1990). Once Upon a Time. Using stories in the language classroom. ( $6^{\text {hh }} E d$.). Cambridge: Cambridge University Press.

Nation, P., \& Meara, P. (2010). Vocabulary. In Schmitt, N. (ed). An Introduction to Applied Linguistics (pp. 34-52). London: Hidder Education.

Seliger, H., Shohamy E. (1990). Second language research methods ( $\left.2^{n d} e d\right)$. Oxford: Oxford University Press.

Silverman, D. (2013). Doing Qualitative Research. (4th $e d)$. Sage Publications Ltd. 